\title{
ПЕРСПЕКТИВЫ НЕФТЕГАЗОНОСНОСТИ СЕВЕРО- АБШЕРОНСКОГО АРХИПЕЛАГА ЮЖНО- КАСПИЙСКОЙ ВПАДИНЫ В СВЯЗИ С ТЕКТОНИЧЕСКИМ РАЗВИТИЕМ СТРУКТУР
}

\author{
Насибова Г. Д., Мухтарова Х. 3. \\ Азербайджанский Государственный Университет Нефти и Промышленности \\ Азербайджан, Баку
}

DOI: https://doi.org/10.31435/rsglobal_wos/31102019/6735

\section{ARTICLE INFO}

Received: 22 August 2019

Accepted: 11 October 2019

Published: 31 October 2019

\section{KEYWORDS}

South Caspian depression, Productive Series, gas-condensate, structure.

\begin{abstract}
Over the past decades, discovery of giant hydrocarbon fields at the depth of above $10 \mathrm{~km}$ in the World oceans enables the possibility of identifying oil and gas at great depths of the South Caspian depression (SCD).

The main oil and gas resources in this region are associated with the Productive Series (PS) -Red Series (RS) of the Lower Pliocene. Paleogene-Miocene and Mesozoic sediments in the southern Caspian are submerged to great depths, the prospects of their oil and gas potential are associated with the most uplifted tectonic zones.

The Northern Absheron, that is considered as one of the promising areas of this region, covers the uplifts zone under the same name that is the most elevated tectonic unit of the South Caspian. The zone under consideration consists of two anticlinal lines, within which about 20 structures have been identified and explored. Currently, about 10 structures are covered by prospecting and exploration drilling and 5 prospective oil and gas structures have been identified: Absheron kupesi, Western Absheron, Novkhany, Ashrafi, Garabakh.Testing of exploration wells on the structures Gilavar, Hali, Arzu, Ashrafi, Mardakan-deniz and Oguz has not been positive. It should be noted that the deep structure of these uplifts is poorly studied by seismic exploration. Detailed integrated geophysical survey at modern technological and methodological levels is necessary to examine the relation of structural plans of sediments of various ages. The prospects oil and gas field exploration are associated with the lower part of the PS, Miocene, Cretaceous and Jurassic.

It should be noted that despite negative conclusions of some foreign researchers on non-productiveness of the structures above, in recent years, the data obtained from the results of new geological and geophysical methods give SOCAR the basis to resume exploration drilling without involvement of foreign companies.
\end{abstract}

Citation: Nasibova G. J., Mukhtarova Kh. Z. (2019) Oil and Gas Prospectivity of the Northern Absheron Archipelago of the South Caspian Depression in Connection with Tectonic Evolution of Structures. International Academy Journal Web of Scholar. 10(40), doi: 10.31435/rsglobal_wos/31102019/6735

Copyright: (C) 2019 Nasibova G. J., Mukhtarova Kh. Z. This is an open-access article distributed under the terms of the Creative Commons Attribution License (CC BY). The use, distribution or reproduction in other forums is permitted, provided the original author(s) or licensor are credited and that the original publication in this journal is cited, in accordance with accepted academic practice. No use, distribution or reproduction is permitted which does not comply with these terms.

В последние десятилетия в результате открытия гигантских углеводородных месторождений в Мировом океане на глубине более 10 км подтверждается возможность обнаружения нефти и газа на больших глубинах и в акватории Южно-Каспийской впадины (ЮКВ), представляющей крупный высокоперспективный нефтегазоносный район $[1,2,3]$.

Разработка и открытие новых углеводородных месторождений, всесторонняя изученность позволяют считать этот район главным объектом поисково-разведочных работ на 
шельфе Каспийского моря на период до 2050 года. Основные ресурсы нефти и газа данного региона связаны с продуктивно-красноцветной толщей нижнего плиоцена.

Палеоген-миоценовые и мезозойские отложения в акватории Южного Каспия погружены на большие глубины, перспективы их нефтегазоносности связываются с наиболее приподнятыми тектоническими зонами $[4,5]$.

Северо-Абшеронский нефтегазоносный район охватывает одноименную зону поднятий, являющуюся наиболее приподнятым тектоническим элементом Южного Каспия. В пределах рассматриваемой нами зоне выявлено и разведано около 20 структур. В пределах северозападной части Южного Каспия установлено широкое развитие элементов погребенных поднятий в различных интервалах разреза.

С ловушками, образованными палеорельефом, связаны залежи нефти и газа. Установлено наличие некоторого несоответствия структурных планов по верхам среднеплиоцен-четвертичного комплекса отложений и отдельным горизонтам нижнего плиоцена, которой обуславливают наличие погребенных поднятий. Этот факт помимо практического интереса, в смысле поиска залежей УВ в подошвенных свитах, представляет также научный интерес, т.к. освещает историю геологического развития бассейна, в раннем этапе среднего плиоцена.

Выявлено, что наиболее песчаные разности отложений нижнего отдела среднего плиоцена приурочены к складкам сформировавшиеся в западной части Абшеронского архипелага (Дан Улдузу, Ашрафи, Хамдам, Карабах, С.Вургун). Наблюдается общая тенденция увеличения мощности среднего плиоцена - продуктивной толщи (ПТ) в юг-юго-восточном направлении в сторону центральной части Южно-Каспийской впадины.

В настоящее время поисково-разведочным бурением охвачены структуры Абшеронкюпеси, Гилавар, Хазри и др. Выявленные нефтегазоносные структуры Абшерон кюпеси, Западно-Абшеронская, Новханы, Ашрафи, Гарабах, являются перспективными. На поднятиях Абшеронкюпеси, Гошадаш, Хазри изучаются перспективность отложений нижнего отдела продуктивной толщи (ПТ) нижнего плиоцена (в крыльевых частях структур) и подстилающие (мезозойские, палеоген-миоценовые) отложения. Мы решили более детально изучить структуры Дан Улдузу, Ашрафи, Хамдам, Карабах и им. Самеда Вургуна, которые относятся к одной и той же антиклинальной линии.

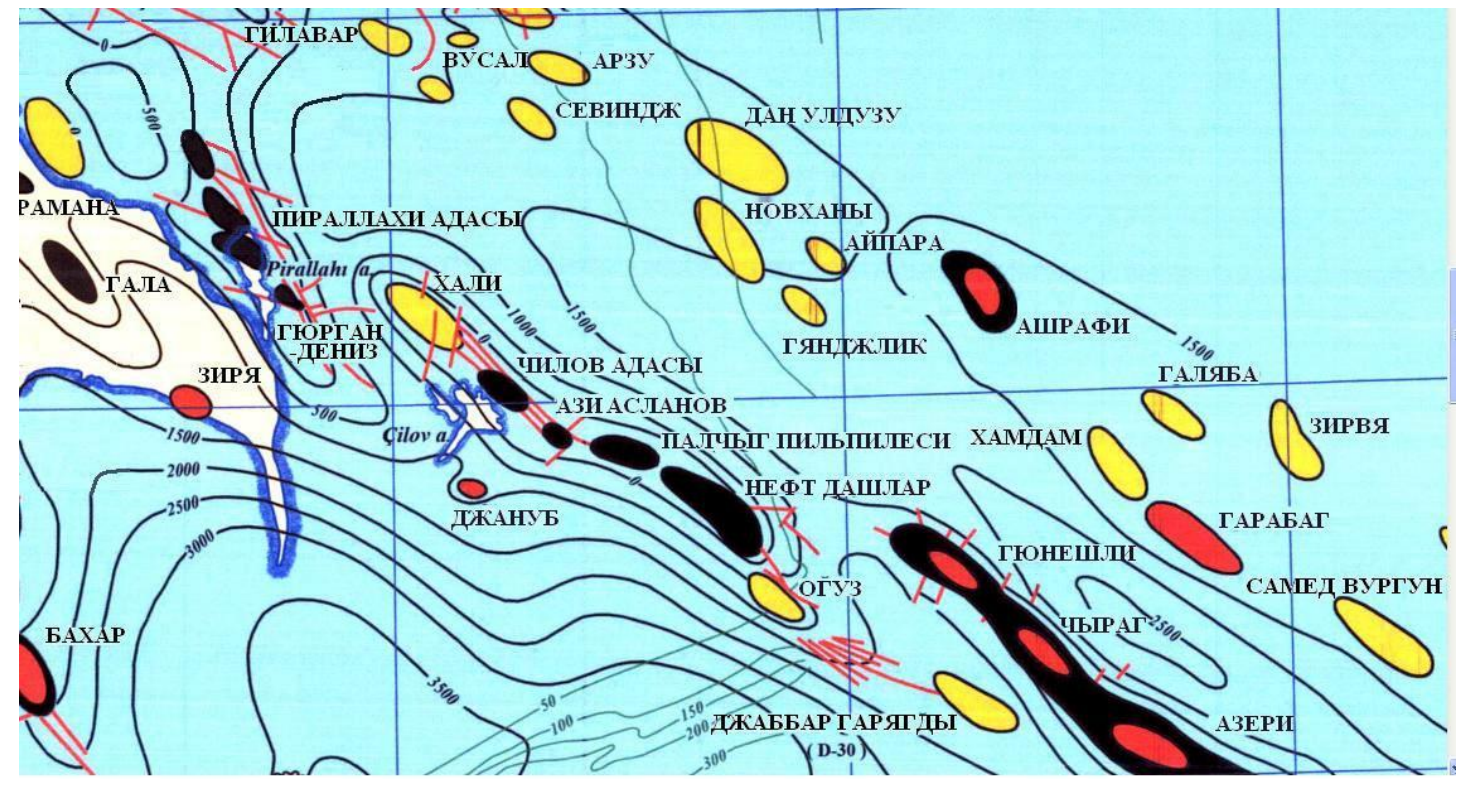

Рис. 1. Нефтегазоносные структуры ЮКВ

Перспективная структура Дан Улдузу расположена в 110 км к северо-востоку от г. Баку и отделяется от структуры Ашрафи небольшой седловиной (РИС. 1, 2). Структура обнаружена сейсморазведкой в 1965 году. В 1998 году здесь было пробурено две поисковые скважины (DU-1, DU-2). При испытании одного из объектов, приток газа и газоконденсата составили соответственно 620 тыс. м ${ }^{3}$ и 40 тонн в сутки. Испытание второго объекта дало приток 460 тонн нефти и 36 тыс. м газа в сутки. Прогнозируемые запасы нефти и газа на этой площади составляют почти 100 млн. тонн нефти и 40 млрд. м³ газа $[3,4,5,6]$. 


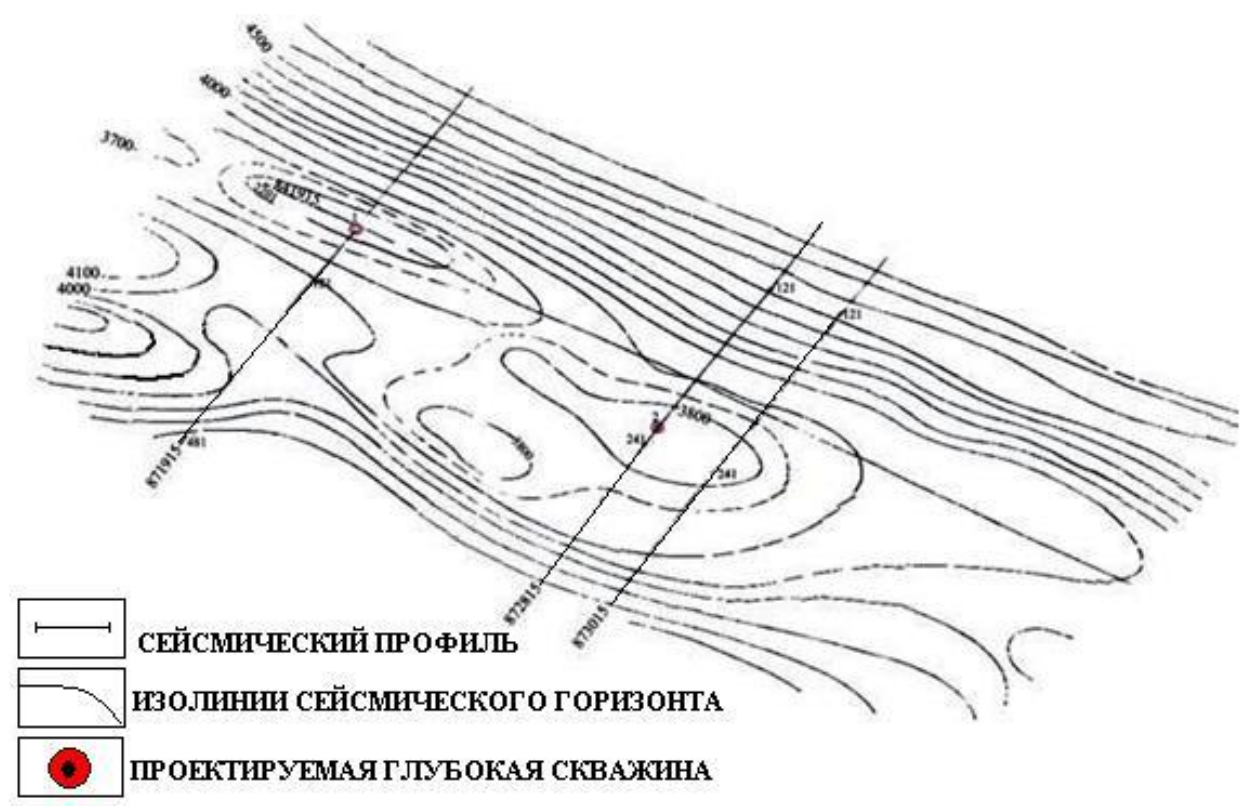

a)

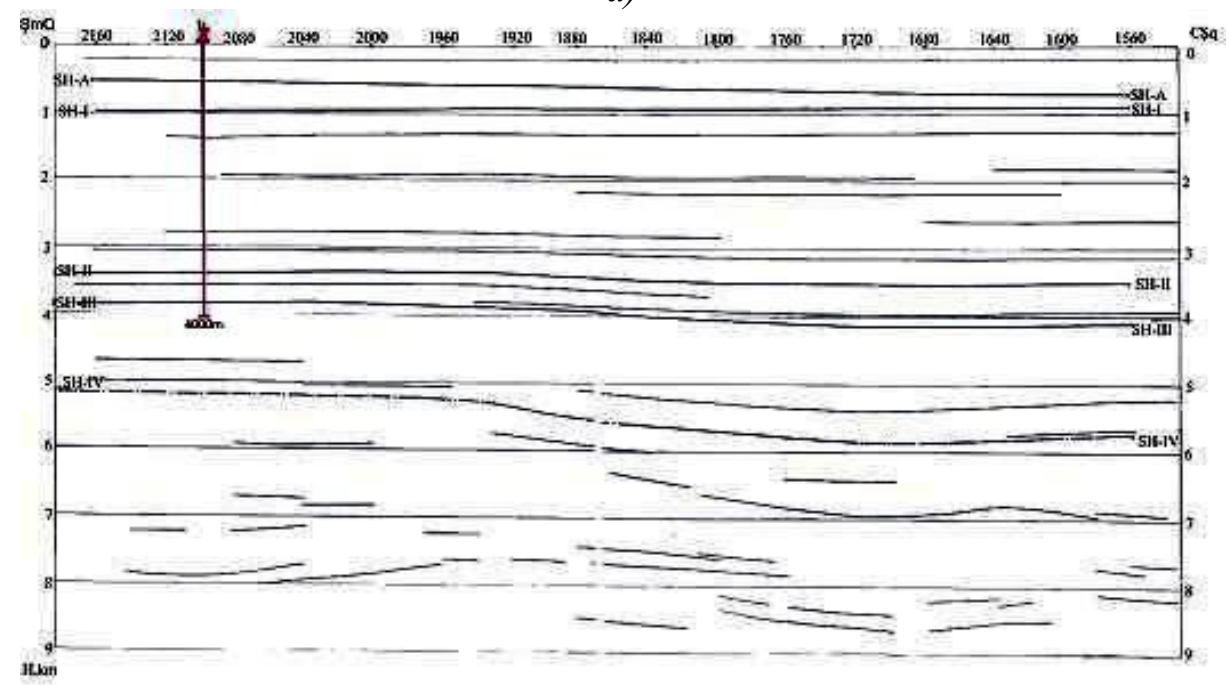

б)

Рис. 2. Структуры Дан Улдузу и Ашрафи: а - Структурная карта по подошве ПТ; б - сейсмический профиль по линии 871915

Структура Ашрафи расположена в 105 км к северо-востоку от г. Баку, в северной части Апшеронского архипелага (рис. 2, а; 3). В этом районе глубина моря достигает 80-180 м. Площадь структуры составляет около 453 км². $^{2}$

В 1997 году здесь проведена трехмерная сейсмосъемка и установлено местоположение 3-х разведочных скважин. В 1998 году разведочной скважиной «Ашрафи -1» (3711 м) в отложениях кирмакинской (КС) (3274-3283) и подкирмакинской (ПК) (3524-3536 м) свит обнаружено газоконденсатное месторождение с первичной оценкой запасов 6-8 млн. тонн. А в целом по структуре первичный запас оценивается цифрой около 50 млн. т газоконденсата $[7,8,9]$.

Характеристика предпологаемых перспективных горизонтов (от X горизонта Балаханской свиты до калинской свиты) приблизительно от 3020 м глубин: Х горизонт Балаханской свиты 200м, свита Фасиля - 120м, НКП - 120 м, КСв - 200м, ПКСв - 140м, КаСв - 440м.

С геотектонической точки зрения структура Ашрафи относится к Приабшеронской линии Абшерон-Прибалханской тектонической зоны. 


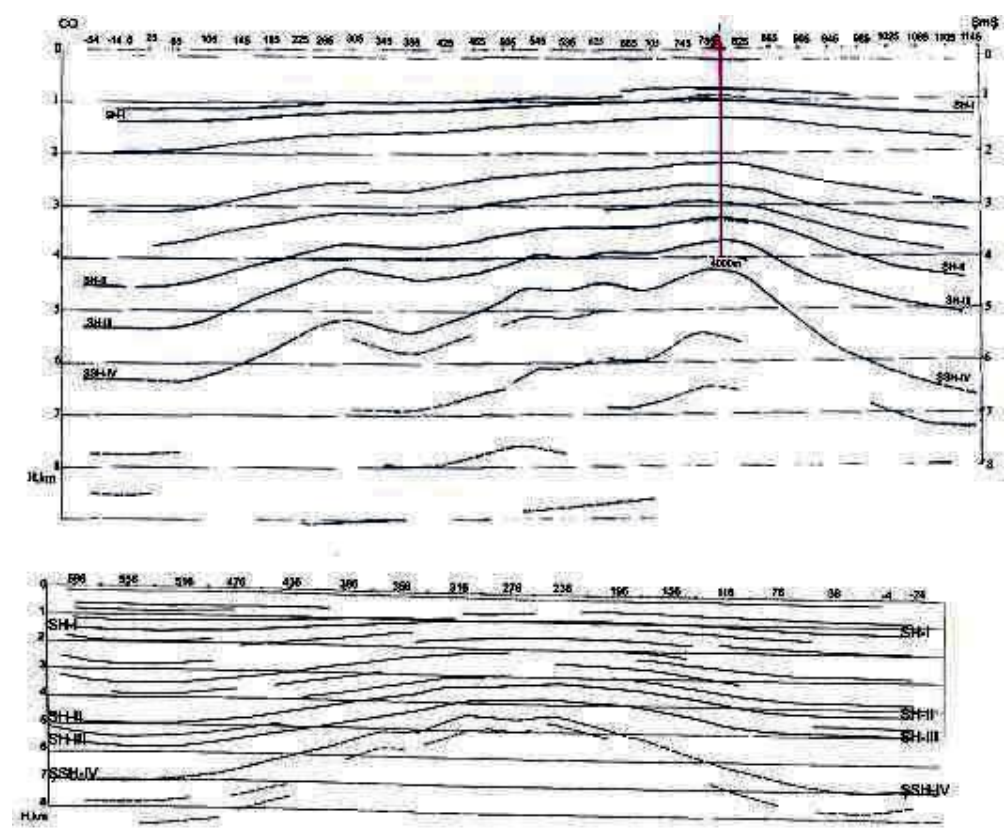

Рис. 3. Глубинный разрез по сейсмическим профилям 872815 и 873015 (услов. обоз. см. рис. 2)

Структура Хамдам расположена в 110км к востоку от г. Баку в восточной части Абшеронского архипелага (рис. 4, 5 а, б). С геотектонической точки зрения структура относится к Абшерон-Туркменбашинской тектонической зоне. Предпологаемыми перспективными объектами можно считать нижний отдел ПТ (НКП, КСвПКС, КаСв), которая залегает в глубине 3300 м и имеет мощность 800м. Прогнозный запас по категории $\mathrm{C}_{2}$ оценивается 20 млн.т. нефти и 10 млд. м природного газа $[10,11,12]$.

В 1979 году была проведена трехмерная сейсмосъемка (ОГТС- общеглубинная точечная съемка) в результате чего была выявлена брахиантиклинальная, асимметричная структура, простирающаяся с северо-запада в юго-восток. Северо-восточное крыло относительно пологий $\left(2-4^{0}\right)$, а юго-западное крутое $\left(9-18^{0}\right)$.

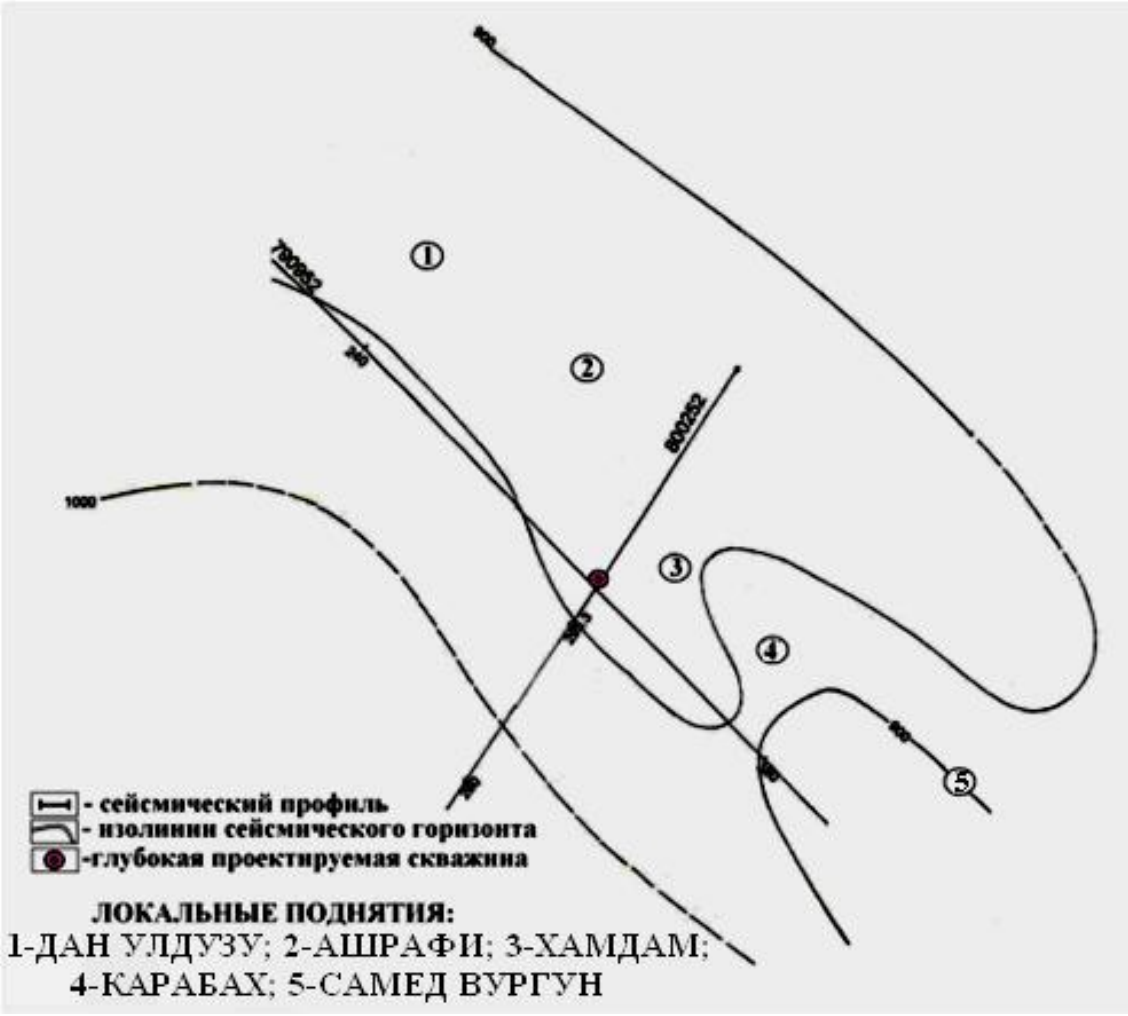

Рис. 4. Площзадь. Хамдам. Структурная карта по подошве ПТ 

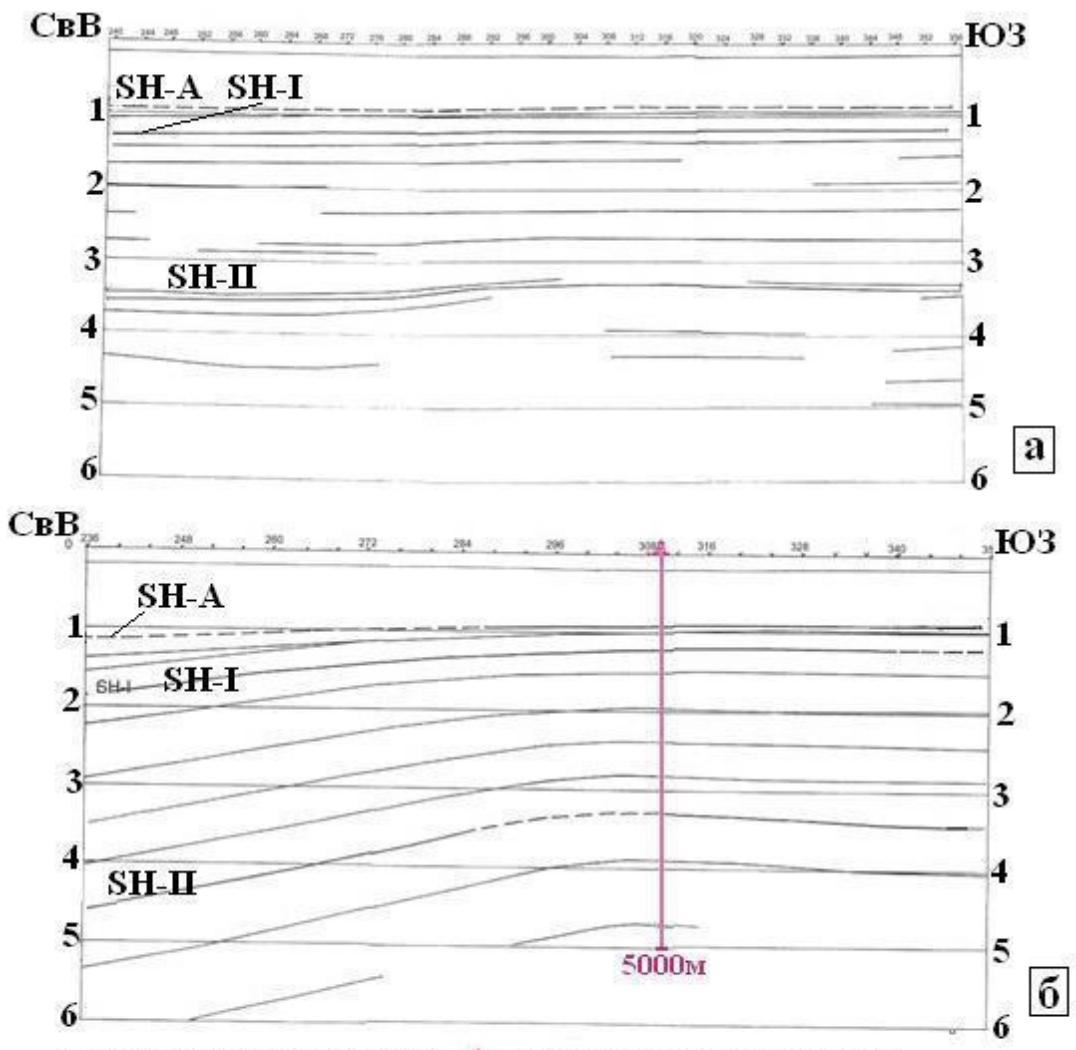

---- -гранцща отраженшя; 庶-проектная скважина;

SH-A -сейсмптеский горизонт (СМГ) в Абшероне;

SH-I -близкий CMГ к продуктивной толшщ (IIT);

SH-II -CMT в IIT.

Рис. 5. Структура Хамдам. Глубинный разрез по сейсмическим профилям 790952 (а) и 800252 (б)

Перспективная структура Карабах находится в 120 км к востоку от г. Баку (рис. 6, 7 - a, б).

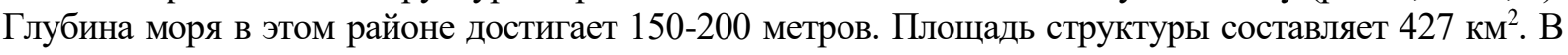
1998 году здесь с плавучей буровой установки (ПБУ) было пробурено 3 поисковых скважины (KPS-1,2,3), в которых проведены геофизические исследования. В скважине №2 (3809) в КС и ПКсвитах получен промышленный приток газа и конденсата. По сейсмическими данными, первичный прогнозный запас углеводородов площади составляет около 80-100 млн. тонн.

Следует отметить, что, несмотря на ряд отрицательных заключений некоторых зарубежных исследователей о бесперспективности вышеуказанных структур, в последние годы полученные данные по результатам проведения с применением новых геолого-геофизических методов, дает основание Государственной Нефтяной Компании Азербайджана (SOCAR) без привлечения иностранных компаний возобновить разведочное бурение на данных структурах [13].

Структуры Дан Улдузу, Хамдам, Гарабаг, им. С.Вургуна, входящие в одну антиклинальную линию, должны стать в ближайшем будущем объектами глубокого поискового бурения. Нельзя не учитывать, что с гипсометрической глубиной и увеличением глинистости тяжелые нефти сменяются все более легкими, а затем нефтяные залежи сменяются залежами газа и конденсата.

Нефтегазоносный район Абшеронского архипелага охватывает акваторию шельфа, прилегающего к Абшеронскому полуострову и Абшеронский порог до поднятия Кяпяз включительно. В Азербайджанском секторе моря этот район характеризуется коллекторами в ПТ, литофациально представленными хорошо отсортированными кварцевыми песками с высокими значениями пористости и проницаемости. Ритмичное чередование песчаных коллекторов и глинистых покрышек, а также благоприятные структурные образования обусловили насыщение углеводородами всего разреза ПТ Абшеронского архипелага, где в отдельных случаях выделяются до 20 залежей. 


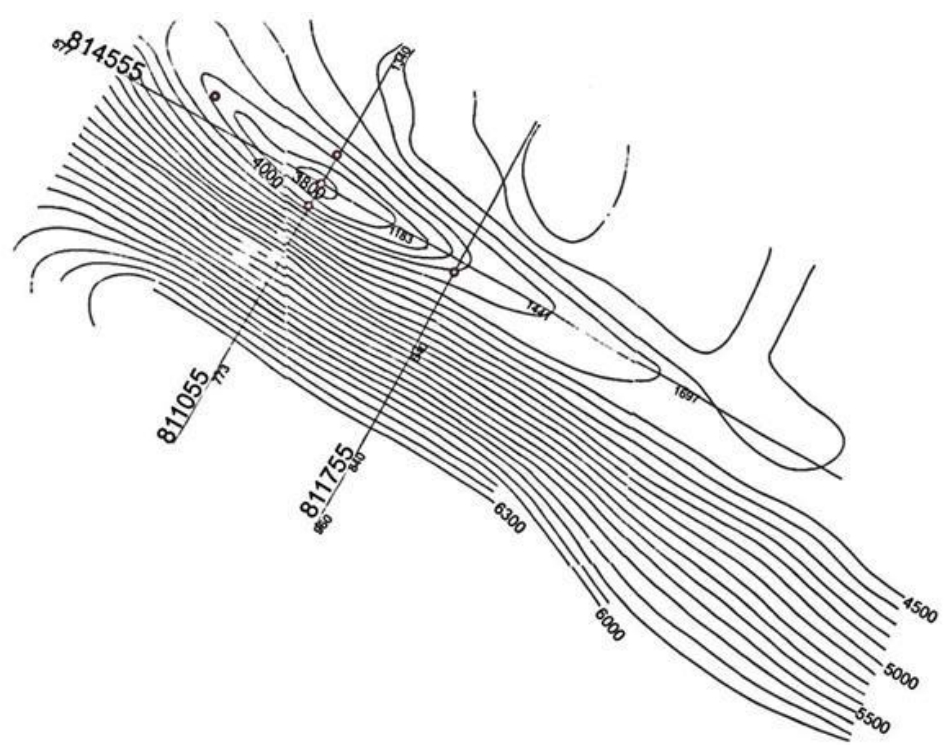

a)

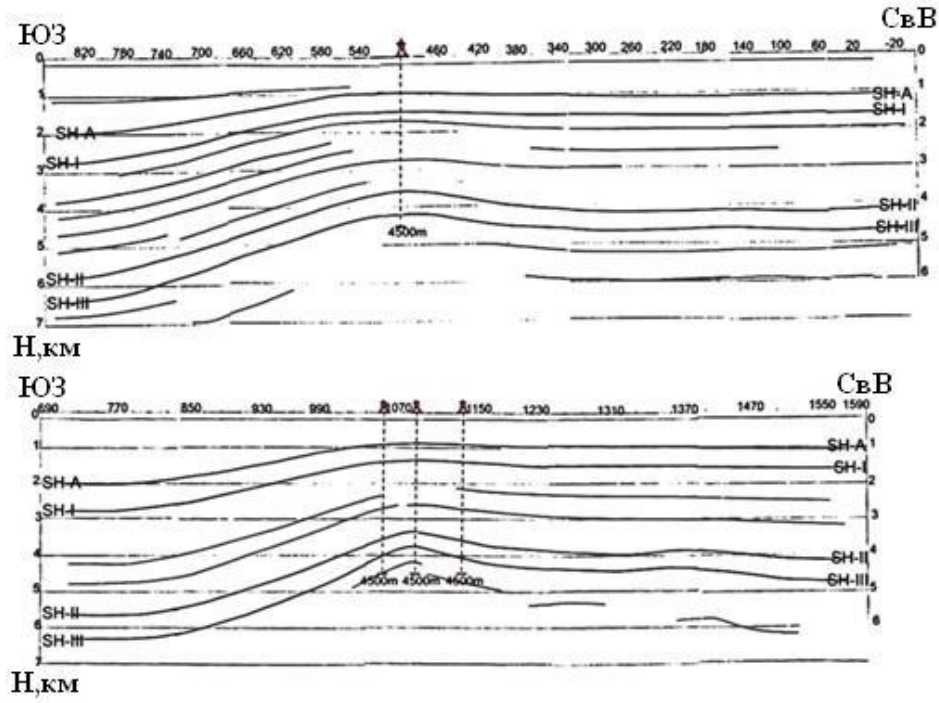

б)

Рис. 6. Площадь Карабах. Структурная карта по подошве ПТ и глубинный разрезпо сейсмическим профилям811055 (а) и 811755 (б) (услов. обоз. см. рис 2)

Выводы. Проведенное геолого-геофизическое исследование всего имеющегося фактического материала бурения и опробования скважинвсеверо-западной части Южного Каспия позволило сделать следующие основные выводы:

1. В пределах исследуемого региона отложения нижнего отдела ПТ, представленные чередованием глин, песков, песчаников, алевролитов, накапливались в условиях интенсивного и компенсированного прогибания Южного Каспия, что является благоприятным для скопления углеводородов.

2. Установлено наличие некоторого несоответствия структурных планов по верхам среднеплиоцен-четвертичного комплекса отложений и отдельным горизонтам нижнего плиоцена, которой обуславливают наличие погребенных поднятий.

3. Выявлено, что наиболее песчаные разности отложений нижнего отдела среднего плиоцена приурочены к складкам сформировавшиеся в западной части Абшеронского архипелага (Дан Улдузу, Ашрафи, Хамдам, Карабах, С.Вургун). Наблюдается общая тенденция увеличения мощности среднего плиоцена - продуктивной толщи (ПТ) в юг-юго-восточном направлении в сторону центральной части Южно-Каспийской впадины.

4. Изучаемые нами складки - Дан Улдузу, Ашрафи, Хамдам, Карабах и С.Вургун, по сравнению с остальным складкам, которые сформировались вблизи, испытали более интенсивный рост и развитие в верхнем плиоцене и антропогене. 
5. Установлено, что относительные скорости роста антиклиналей в течение отдельных отрезков геологического времени изменяются. Максимальные значения относительной скорости подъема структур характерны для КаС и ПК времени. По всей вероятности, это свидетельствует об ускоренном росте поднятий в до среднеплиоценовое время, что, возможно, привело к выклиниванию осадков КаС и к частичному размыву отложений ПК свиты на сводовых участках этих поднятий.

6. Залежи нефти и газоконденсата структурного класса приурочены к антиклинальным поднятиям, осложненным грязевыми вулканами и разрывными нарушениями, и относятся к сводовым, тектонически экранированным и блоковым типам. В залежах флюиды распределяются по закону гравитации.

7. Кондедиментационные разрывы в процессе своего развития были как проводящими каналами, так и тектоническими экранами для углеводородов.

8. Зоной нефтегазообразования для месторождений исследуемого нами региона является Южно Каспийская впадина, испытавшая за время накопления среднего плиоцена и верхнего плиоцена наиболее интенсивное погружение, где происходила генерация углеводородов и их миграция в сторону антиклинальных зон. Однако, допускается миграция определенной части углеводородов в Южно-Каспийской впадине снизу по глубинным разломам с последующим их накоплением в структурных ловушках.

9. С целью детального изучения геологического строения следует продолжить здесь комплексные геофизические исследования. Так, по новым сейсмическим данным достаточно уверенно можно предположить, что сводовые части многих погребенных структур не нарушены, и по сейсмическим особенностям эти структуры представляют практический интерес для поиска залежей УВ в отложениях ПТ и Абшеронского яруса.

\section{ЛИТЕРАТУРА}

1. Али-заде А.А., Ахмедов Г.А., Ахмедов А.М., Алиев А.К., Зейналов М.М. - Геология нефтяных и газовых месторождений Азербайджана. // Изд.: Недра, 1966. 390 с.

2. Ализаде А.А., Салаев С.Г., Алиев А.И., 1985. Научная оценка перспектив нефтегазоносности Азербайджана и Южного Каспия и направление поисково-разведочных работ.- Баку: ЭЛМ, 252 с.

3. Юсифзаде Х.Б., Велиева Э.Б., 1994 г. Нефтегазовая промышленность Азербайджана: состояние, проблемы, перспективы // Материалы международной научно-практической конференции. - Москва, с. 36-41

4. Юсифов Х., Асланов Б. «Нефтегазоносные бассейны Азербайджана», Баку, 2018, 323 стр.

5. Нариманов Н.Р., Мухтарова Х.З., Насибова Г.Д. Геологическое развитие и нефтегазоносность локальных поднятий Бакинского архипелага Южно-Каспийского бассейна. Известия Томского политехнического университета. Инжиниринг георесурсов. 2019. Т. 330. No 6. 164-173; http://izvestiya.tpu.ru/archive/issue/view/97; https://www.scopus.com/sourceid/21100812103? origin=resultslist

6. Мехтиев Ш.Ф. «Избранные труды», Баку 2010, 474 стр.

7. 10.Алиев А.Г. «Избранные труды», Баку, 2011, 527 стр.

8. Н.Р.Нариманов, С.М.Рзаева Особенности развития и нефтегазонасыщения резервуаров локальных поднятий Абшеронского архипелага. ANT, 2010, №7, стр.7-13

9. А.А.Али-Заде, С.Г.Салаев, А.И.Алиев. Научная оценка перспектив нефтегазоносности Азерб.на и Южного Каспия и направление поисково-разведочных работ. Баку, Элм, 1985, стр. 8-16

10. А.А.Ализаде Геология Азербайджана. Т.1. Стратиграфия, ч.2-я. Мезозой и кайнозой. Баку, 2007, с. 18-234

11. А.А.Али-заде, Г.А.Ахмедов, А.М.Ахмедов и.др. Геология нефтяных и газовых месторождений Азербайджана.Изд. "НЕДРА", 1996, 279 стр.

11. Н.Р.Нариманов. Влияние геодинамических процессов на нефтегазообразование в Южно-Каспийской впадине AHX, N8, 2008, стр. 7-16

12. Babayev Nariman, Gahramanov Gahraman, Zohrab Javad-Zadeh. Cenozoic stag of development of local structures of the Lower Kura Depression and Baku Archipelago related to their oil and gas prospectinvity. Geological Journal. SPI Journal Code Article ID, GJ 3304. Accepted: 2 July 2018, DOL10.1002/gi.3304 